\title{
Correlation of $p 16$ Hypermethylation with p16 Protein Loss in Sporadic Gastric Carcinomas
}

\author{
Yhong-Hee Shim, Gyeong Hoon Kang, and Jae Y. Ro \\ Molecular Pathology Laboratory, Department of Diagnostic Pathology, Asan Medical Center, University of Ulsan, \\ College of Medicine, Seoul, Korea
}

\begin{abstract}
SUMMARY: Hypermethylation of $p 16$ has been detected frequently in a variety of cancer cells and is known to repress the level of $p 16$ transcription. In human gastric carcinoma (GC) cells, p16 protein loss has often been detected, but genetic alterations of $p 16$ are infrequent. To investigate the molecular mechanism of $p 16$ gene inactivation in gastric carcinogenesis, we examined the methylation status of $p 16$ in GC using methylation-specific PCR. Thirty-seven of eighty-eight (42\%) GC showed p16 hypermethylation. Immunohistochemical analysis of 41 cases of GC showed a complete loss of p16 immunoreactivity in 19 of 22 (86\%) methylation-positive cases, but in only 2 of 19 (11\%) methylation-negative cases. Of 88 GC, 21 cases were previously identified as having microsatellite instability (MSI). Interestingly, 13 of 21 (62\%) MSI-positive tumors and 24 of 67 (36\%) MSI-negative tumors had hypermethylation on $p 16$. The relatively high frequency of hypermethylation on $p 16$ and the strong correlation between the immunoreactivity and methylation patterns suggest that methylation is an important mechanism for $p 16$ gene inactivation in GC. (Lab Invest 2000, 80:689-695).
\end{abstract}

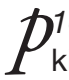
6 , an inhibitor of the cyclin D-dependent protein kinases, is a tumor-suppressor gene, and its mutation and deletion have been reported in a variety of tumors (Kamb, 1995). Reduced expression of p16 results in higher cyclin D-dependent protein kinase activity and therefore in aberrant phosphorylation of $\mathrm{Rb}$, which consequently accelerates cell growth. The roles of $p 16$ gene inactivation in carcinogenesis have been intensively studied in a variety of tumors. The frequency of $p 16$ inactivation has been examined in most studies by looking for either homozygous deletions or genetic mutations (reviewed in Liggett and Sidransky, 1998). Although a high frequency of p16 protein loss has been reported, the mechanism for the loss of expression has not been fully explained by homozygous deletions or genetic mutations. Hypermethylation on the $\mathrm{CpG}$ island of the $p 16$ gene has been proposed as an alternative mechanism for the loss of p16 expression (Herman et al, 1995). Results from the recent studies on hypermethylation of $p 16$ in many types of human tumors indicate that this epigenetic change may contribute to p16 protein loss (Herman et al, 1995; Liew et al, 1999; Matsuda et al, 1999; Schutte et al, 1997; Toyota et al, 1999a).

In human gastric carcinomas (GC), genetic alterations of $p 16$ are infrequent, although $p 16$ is a wellknown tumor-suppressor gene in many different types of human tumors (Gunther et al, 1998; Igaki et al, 1995; Wu et al, 1996, 1998 ). In addition, some GC cell

Received January 18, 2000.

This research was supported by Grant 99-218 (to JYR) from the Asan Life Science Institute, Seoul, Korea.

Address reprint requests to: Dr. Y.-H. Shim, Department of Diagnostic Pathology, Asan Medical Center, 388-1 Pungnap-dong, Songpa-ku, Seoul, 138736, Korea. Fax: 822472 7898; E-mail:yshim@www.amc.seoul.kr lines with no expression of p16 protein have a low frequency of genetic alterations of p16 (Akama et al, 1996). Furthermore, Lee et al (1997) examined both GC cell lines and primary GC for homozygous deletions and genetic mutations in $p 16$. They found that only a small number of cell lines contained either homozygous deletions or mutations of $p 16$, and that none of the primary GC examined showed any alterations. Interestingly, however, only 1 of 10 primary tumors tested had detectable p16 mRNA expression Lee et al (1997). These results strongly indicate that an alternative mechanism is responsible for $p 16$ inactivation in these tumors. Recently, a high frequency of $p 16$ hypermethylation in GC was reported (Suzuki et al, 1999), and the CpG island methylator phenotype was suggested to be a potential pathway in gastric carcinogenesis (Toyota et al, 1999b).

To determine the relationship between the methylation status of the $p 16$ gene and the expression of $p 16$ protein in GC, we examined the methylation status of p16 using methylation-specific PCR (MSP), and performed immunohistochemical and bisulfite sequencing analyses. We conclude that hypermethylation of p16 is the major mechanism for p16 protein loss in GC.

\section{Results} High Frequency of Hypermethylation on the CpG Islands
of the p16 Gene

Aberrant hypermethylation on the $\mathrm{CpG}$ island of the p16 gene was detected in 37 of 88 (42\%) GC by MSP, as described in "Materials and Methods" (Fig. 1A). None of the corresponding normal tissues of these 37 tumors with $p 16$ hypermethylation had methylated p16 genes (Fig. 1B). Specificity of p16 methylation 

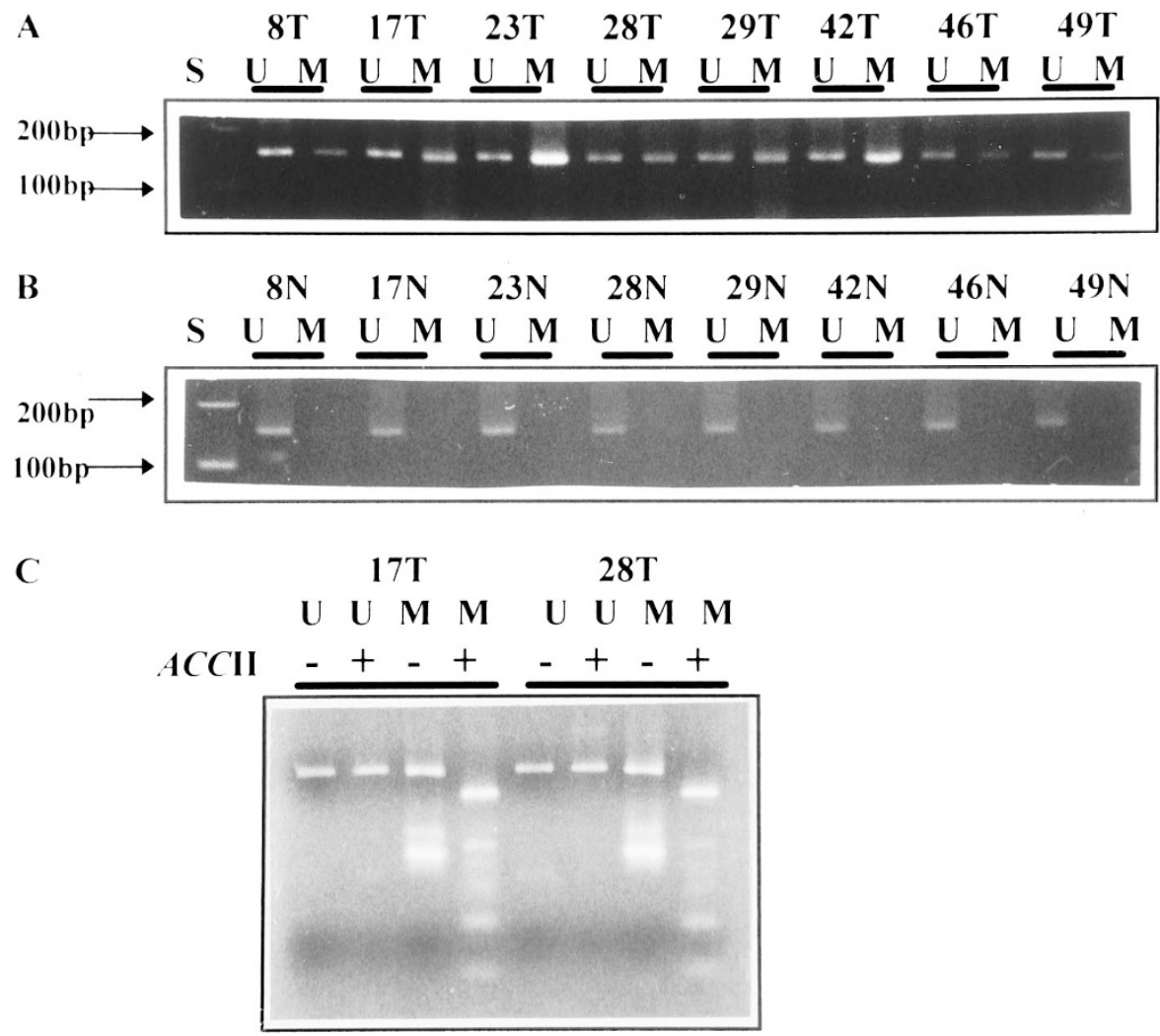

\section{Figure 1.}

Methylation analysis of $p 16$ in gastric carcinomas. (A) DNA extracted from tumors (cases 8, 17, 23, 28, 29, 42, 46, and 49) and (B) DNA extracted from the corresponding normal tissues were amplified by PCR with primers specific to the unmethylated $(U)$ or the methylated $(M)$ CpG islands of the $p 16$ gene after modification with sodium bisulfite. The expected sizes of the PCR products of $p 16$ were 151 bp with U primers and 150 bp with M primers. (C) ACC II restriction digestion analysis on the PCR products of DNA extracted from tumor cells of cases 17 and 28. Only products amplified with M primers were digested with ACC II. Molecular size markers are in $S$ lanes.

status was confirmed by digestion with ACC II, which cuts the restriction site CGCG. Only the restriction site with methylated cytosine was digested, because methylated cytosine remains after bisulfite treatment, maintaining the CGCG site. Unmethylated cytosine is changed to uracil after bisulfite treatment and becomes thymine during PCR amplification, which changes the ACC II recognition site, CGCG, to TGTG, which is restricted to cleavage (Fig. 1C). Clinicopathologic parameters such as age, sex, and histologic differentiation of GC were not significantly associated with the methylation status (data not shown).

\section{Immunohistochemical Analysis of p16 Protein Expression}

To determine whether $p 16$ hypermethylation results in p16 protein loss, tumors and corresponding normal tissues from 41 cases of GC (22 methylation-positive cases and 19 methylation-negative cases) were immunohistochemically examined. In all sections, nonneoplastic cells had nuclear p16 protein immunoreactivity (Fig. 2). Nineteen of twenty-two (86.4\%) methylation-positive cases had a complete lack of immunoreactivity (Fig. 2A, Table 1). In contrast, 17 of 19 (89.5\%) methylation-negative cases were p16 immunoreactive (Fig. 2B, Table 1). Importantly, a strong correlation was observed between the immunohisto- chemical results and the methylation status ( $p=$ 0.0001 , Fisher's Exact test). Most tumors (86.4\%) with hypermethylation were not immunoreactive for the p16 protein (the three exceptions were cases 15, 17, and 50), indicating that the p16 protein loss was strongly associated with hypermethylation of the $p 16$ gene.

\section{Methylation Density of CpG Islands in the p16 Gene}

Immunohistochemical analysis revealed that three cases (cases 15, 17, and 50) had p16 immunoreactivity although they were hypermethylated. This discrepancy between the methylation status and the immunoreactivity pattern could be related to the methylation density of $\mathrm{CpG}$ islands, because it has been shown that the level of transcriptional repression is dependent on the methylation density (Hsieh, 1994; Matsuda et al, 1999). To verify this point, we examined tumor DNA from case 17 for relative $\mathrm{CpG}$ methylation density of the p16 gene using bisulfite sequencing analysis. We isolated and sequenced individual clones of the amplified PCR products (either $151 \mathrm{bp}$ with $U$ primers or $150 \mathrm{bp}$ with $\mathrm{M}$ primers) for the p16 gene, covering the region from +167 to +317 , which contains $19 \mathrm{CpG}$ sites. The results obtained from case 17 were compared with those from cases 23 and 42 , 

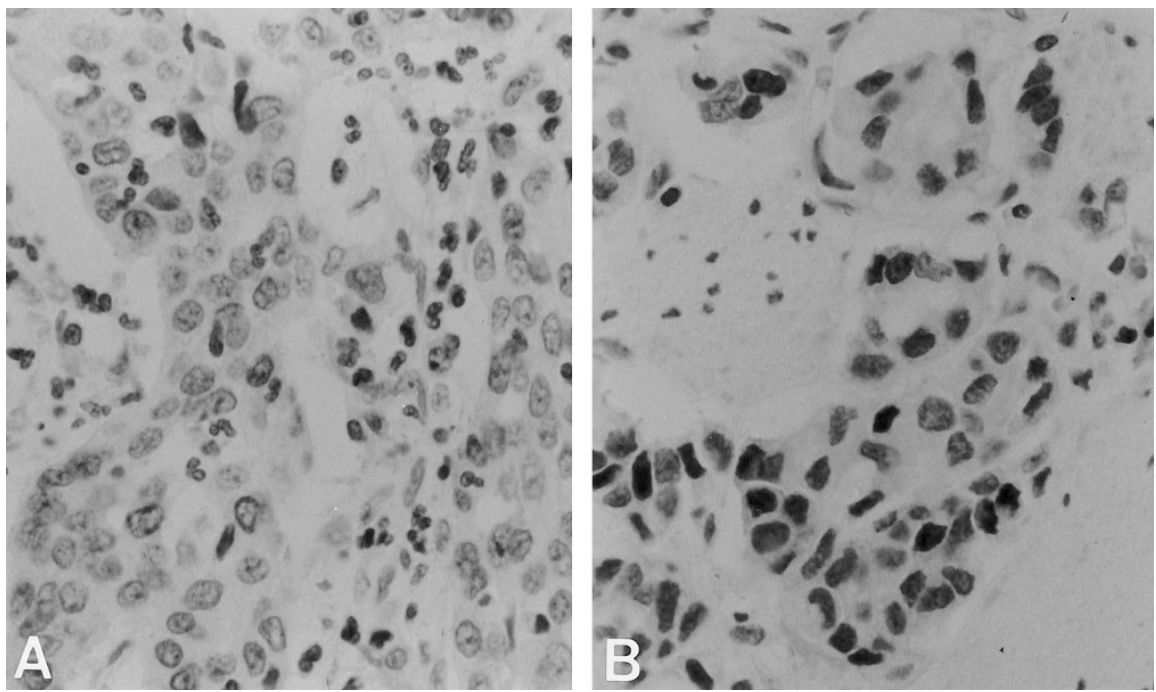

\section{Figure 2.}

Immunohistochemical analysis of p16 expression in gastric carcinomas (original magnification, $\times 400$ ). (A) Tumor cells in solid arrangement were not p16 immunoreactive, in contrast to background stromal and inflammatory cells, which were immunoreactive (case 8, methylation-positive). (B) Tumor cells in glandular arrangement had p16 expression (case 27, methylation-negative).

Table 1. Frequency of p16 Protein Loss in GCs with p16 Hypermethylation

\begin{tabular}{lccc}
\hline & \multicolumn{2}{c}{ p16 Immunostaining } & \\
\cline { 2 - 3 } p16 Methylation & \multicolumn{1}{c}{+} & \multicolumn{1}{c}{ Total } \\
\hline Positive & 3 & $19(86.4 \%)$ & 22 \\
Negative & $17(89.5 \%)$ & 2 & 19 \\
Total & 20 & 21 & 41 \\
\hline
\end{tabular}

which were both positive for methylation and negative for p16 immunoreactivity (Fig. 3). Surprisingly, the methylation density of $\mathrm{CpG}$ islands from each tumor DNA amplified with $M$ primers varied both in different tumors and even within the same tumor. In case 17, the methylation density ranged from dense to intermediate in methylated DNA (from 100\%, all 11 CpG sites (four clones) methylated, to 45\%, 5 CpG sites (one clone) methylated) whereas individual clones obtained from cases 23 and 42 were extensively methylated (degree of methylation ranged from $82 \%$ to $100 \%$ ). The methylated sites also varied in different clones: that is, different sites were unmethylated. The corresponding unmethylated DNA (17U, 23U, and 42U amplified PCR products with $U$ primers) showed that all of the $11 \mathrm{CpG}$ sites were virtually unmethylated (Fig. 3). This demonstrated that CpG sites of the p16 gene were completely unmethylated in unmethylated DNA but that overall, the methylation density for methylated DNA varied.

\section{Loss of Heterozygosity (LOH) on Chromosome 9p21}

Three samples in our study were negative for both p16 immunoreactivity and methylation (cases 6, 25, and 33). This result suggested alternative mechanisms for the $\mathrm{p} 16$ protein loss in these three cases. As homozy- gous deletions and genetic mutations of p16 are uncommon in GC (Gunther et al, 1998; Igaki et al, 1995; Lee et al, 1997; Wu et al, 1996, 1998), we performed LOH study on chromosome 9p21 at three loci: D9S171, D9S1679, and D9S165 (data not shown). None of the three samples showed $\mathrm{LOH}$ at any of three loci.

\section{High Frequency of p16 Hypermethylation in Tumors with Microsatellite Instability (MSI)}

Hypermethylation of $p 16$ was previously shown to occur at a high frequency in colorectal cancers (Ahuja et al, 1997) and GC (Suzuki et al, 1999) with MSI. These observations led us to test whether this was the case for the GC that we examined. We analyzed 88 cases of GC, including the $21 \mathrm{MSI}$-positive cases (MSI-positive cases were previously identified by detecting $\mathrm{MSI}$ in $30 \%$ or more of examined loci; Kang et al, 1999b). Interestingly, 13 of 21 (61.9\%) tumors with MSI were hypermethylated on the $p 16$ gene, whereas 24 of 67 (35.8\%) tumors without MSI were positive for methylation (Table 2). A statistically significant association between $\mathrm{MSI}$ and $p 16$ methylation was observed ( $p=0.035$, chi-squared test).

\section{Discussion}

It is intriguing that previous studies found that genetic alterations in the p16 gene are uncommon in GC, although the p16 gene is a tumor-suppressor gene that plays an important role with a high relevance to tumorigenesis of a variety of tumor types (Igaki et al, 1995; Lee et al, 1997; Wu et al, 1996, 1998). This leads to speculation that the role for $p 16$ in the carcinogenesis of GC may be underestimated. Here we report a relatively high frequency of $p 16$ hypermethylation ( $42 \%, 37$ of 88 cases) in GC, and the observation that the methylation status was closely related to the loss 
(A)

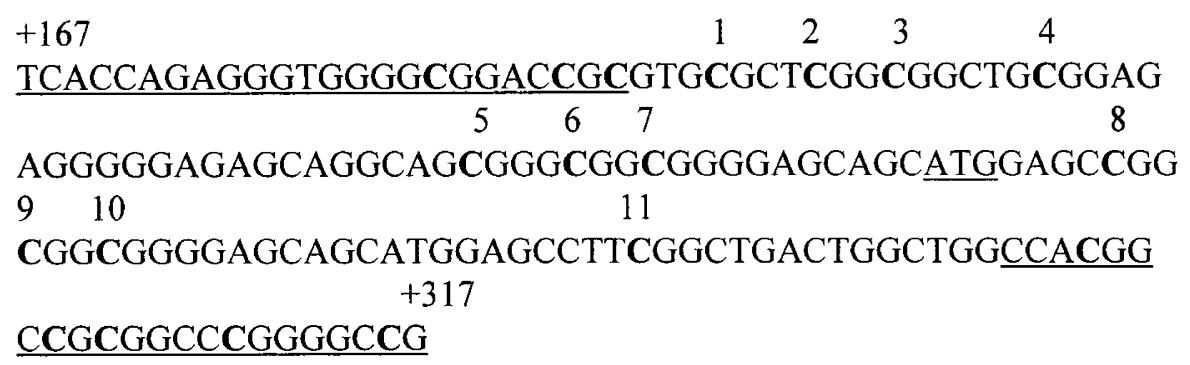

(B)

\begin{tabular}{|c|c|c|c|c|c|c|c|c|c|c|c|c|}
\hline & & 1 & 2 & 3 & 4 & 5 & 6 & 7 & 8 & 9 & 10 & 11 \\
\hline $17 \mathrm{U}$ & & - & - & - & - & - & - & - & - & - & - & - \\
\hline \multirow[t]{5}{*}{$17 \mathrm{M}$} & 1 & + & + & + & + & + & + & + & + & + & + & + \\
\hline & 2 & + & - & + & + & - & - & - & - & + & + & + \\
\hline & 3 & + & + & + & + & + & + & + & + & + & + & + \\
\hline & 4 & + & + & + & + & + & + & + & + & + & + & + \\
\hline & 5 & + & + & + & + & + & + & + & + & + & + & + \\
\hline \multirow{6}{*}{$\begin{array}{l}23 \mathrm{U} \\
23 \mathrm{M}\end{array}$} & & - & - & - & - & - & - & - & - & - & - & - \\
\hline & 1 & + & + & + & + & + & + & + & + & - & + & + \\
\hline & 2 & + & + & + & + & + & + & + & + & + & + & + \\
\hline & 3 & + & + & + & + & + & + & + & + & + & + & + \\
\hline & 4 & + & - & + & + & + & + & + & + & + & + & + \\
\hline & 5 & + & + & + & + & + & + & + & + & + & + & + \\
\hline \multirow{6}{*}{$\begin{array}{l}42 \mathrm{U} \\
42 \mathrm{M}\end{array}$} & & - & - & - & - & - & - & - & - & - & - & - \\
\hline & 1 & + & + & + & + & + & + & + & + & + & + & + \\
\hline & 2 & + & + & + & + & - & + & + & + & + & + & + \\
\hline & 3 & + & + & + & - & + & + & + & + & + & + & + \\
\hline & 4 & + & + & + & + & - & - & + & + & + & + & + \\
\hline & 5 & + & + & + & + & + & + & + & + & + & + & + \\
\hline
\end{tabular}

Figure 3.

Methylation status at $\mathrm{CpG}$ sites of the $p 16$ gene. (A) The nucleotide sequences between +167 to +317 of the $p 16$ gene are shown. The individual $\mathrm{CpG}$ sites between two PCR primers are numbered sequentially. Cytosines at the $\mathrm{CpG}$ site are in bold. The PCR primers and the ATG site are underlined. (B) The methylation status of individual clones obtained from cases 17, 23, and 42 was determined by bisulfite sequencing as described in "Materials and Methods". The methylation status of individual sites is indicated by "+" for methylated sites, and "-" for unmethylated sites. 17U, 23U, and $42 \mathrm{U}$ are clones from the unmethylated DNA of each case; five clones of each were sequenced, and all clones were unmethylated at $\mathrm{CpG}$ sites. 17M, 23M, and 42M are clones from methylated DNA, and sequences of five clones are shown. All sequences presented were read from both strands.

Table 2. Frequency of $p 16$ Hypermethylation in GCs with Microsatellite Instability

\begin{tabular}{lccc}
\hline & \multicolumn{2}{c}{ Microsatellite Instability } & \\
\cline { 2 - 3 } p16 Methylation & \multicolumn{2}{c}{+} & \multicolumn{1}{c}{ Total } \\
\hline Positive & $13(61.9 \%)$ & $24(35.8 \%)$ & 37 \\
Negative & 8 & 43 & 51 \\
Total & 21 & 67 & 88 \\
\hline
\end{tabular}

of p16 protein immunoreactivity: that is, 19 of 22 $(86.4 \%)$ methylation-positive cases were not immunoreactive for $\mathrm{p} 16$. These results raise an interesting point regarding the relationship of $p 16$ hypermethyl- ation to carcinogenesis of GC. Hypermethylation seems to be an important mechanism for $\mathrm{p} 16$ protein loss, which suggests that it could be the primary process in the carcinogenesis of GC, as has been found in other tumor types, such as hepatocellular carcinoma (Liew et al, 1999; Matsuda et al, 1999), colorectal carcinoma (Herman et al, 1995), and pancreatic carcinoma (Schutte et al, 1997).

In our study, 3 of 22 methylation-positive cases (cases 15, 17, and 50) were immunoreactive for the p16 protein. This finding can be explained by three possibilities: a high sensitivity of the MSP method, a partial methylation of the $p 16$ gene, or a hemimethylation of the $p 16$ gene. For the first possibility, MSP is 
very sensitive and can detect methylated DNA at the $0.1 \%$ level (Herman et al, 1996). If tumor cells contained both methylated and unmethylated DNA, and the proportion of methylated DNA were as low as $0.1 \%$ of the total DNA, this sample would be classified as having a methylation-positive pattern, but it would show positive immunoreactivity in $99.9 \%$ of unmethylated tumor cells. Thus, the methylation status detected by the MSP method may be required to correlate with an immunohistochemical analysis to validate the biological function of hypermethylation. For the second possibility, four of five sequenced clones from case 17 had $100 \%$ methylation on $11 \mathrm{CpG}$ sites, but one clone had only $45 \%$ methylation (5 of $11 \mathrm{CpG}$ sites were methylated) (Fig. 3). This partial methylation may have caused positive immunoreactivity for p16 protein in the tumor cells of case 17, which might otherwise have not been immunoreactive because of hypermethylation. It has been reported that reduction of p16 expression is associated with limited $\mathrm{CpG}$ methylation (Foster et al, 1998; Hsieh, 1994). This indicates that incomplete methylation may reduce the level of transcriptional repression, resulting in the partial loss of p16 expression. For the third possibility, hemimethylation of the $p 16$ gene, PCR results showed that both unmethylated and methylated DNA were present in all three cases (Fig. 1A); possibly the unmethylated allele is responsible for the immunoreactivity. Hemimethylated DNA has been reported in cell lines such as the colon carcinoma cell line, HCT116 (Myohanen et al, 1998). Analysis of DNA extracted from primary tumors, however, often found the presence of both methylated and unmethylated DNA. This suggests that the unmethylated DNA could also have come from contamination of normal tissues (Herman et al, 1996; Hsieh et al, 1998; Matsuda et al, 1999). In our study, most cases with hypermethylation and negative immunoreactivity also had unmethylated DNA, suggesting that the amplified unmethylated DNA could be mainly due to contamination from normal tissues. Therefore, the p16 immunoreactivity in those cases is unlikely to be due to $p 16$ hemimethylation.

Three cases were negative for both methylation and immunoreactivity (cases 6, 25, and 33). This suggested that the lack of p16 protein might be attributable to molecular events other than hypermethylation, such as homozygous deletion or genetic mutations. Both of these events, however, are infrequent in GC. In our examination of $\mathrm{LOH}$ at chromosome 9p21, none of these three cases had LOH or homozygous deletion of the p16 gene (data not shown). Genetic mutations on the $p 16$ gene need to be analyzed further, but no mutations or very few mutations have been previously reported in GC (Gunther et al, 1998; Igaki et al, 1995; Lee et al, 1997; Wu et al, 1996, 1998).

In this study, we detected a higher frequency of $p 16$ hypermethylation in GC with MSI (61.9\%). A close relationship between $\mathrm{MSI}$ and aberrant methylation of multiple genes including p16 in colorectal cancer (Ahuja et al, 1997) and GC (Suzuki et al, 1999) has been reported. Our results also support the relationship between methylation and MSI. Our previous study showed that 19 of 21 cases of GC with MSI were positive for $h M L H 1$ gene methylation (Kang et al, 1999a). Furthermore, $h M L H 1$ gene methylation has been reported to be the major mechanism for GC with MSI (Fleisher et al, 1999; Kang et al, 1999a; Leung et al, 1999; Suzuki et al, 1999). In our present study, $35.8 \%$ of MSI-negative cases showed p16 hypermethylation (Table 2), and most of the methylationpositive cases were not p16 immunoreactive (Table 1). This suggests that MSI is associated not with a p16 protein loss, but rather, is associated with the methylation status. Thus, hypermethylation of selective genes may be more responsible for determining specific types of GC, for example, $h M L H 1$ hypermethylation for GC with MSI. Our present findings suggest that hypermethylation of $p 16$ is the major process for p16 gene inactivation in GC and an important mechanism in gastric carcinogenesis.

\section{Materials and Methods}

\section{Tissue Samples}

Eighty-eight sporadic gastric carcinomas (46 fresh tissues and 42 formalin-fixed, paraffin-embedded tissues) were analyzed. None of the tumors met the Amsterdam criteria for hereditary nonpolyposes coIon carcinoma (Vasen et al, 1991). Gastrectomies were performed at Asan Medical Center, Seoul, Korea, between 1996 and 1998. All 88 samples were previously characterized, and 21 cases were identified as MSI-positive tumors (with $\mathrm{MSI}$ of $30 \%$ or more of examined loci) (Kang et al, 1999b). For each tumor, normal gastric epithelium was available for a control.

\section{Immunohistochemistry}

Five micron tissue sections were mounted on silanized DAKO glass slides and baked at $60^{\circ} \mathrm{C}$ for 15 minutes. Slides were deparaffinized in xylene, rehydrated in graded alcohol, and washed in water. Endogenous peroxidase activity was blocked by incubation with $3 \% \mathrm{H}_{2} \mathrm{O}_{2}$. Slides were placed in a cooker filled with 10 $\mathrm{mm}$ citrate buffer ( $\mathrm{pH}$ 6.0) and antigen retrieval was accomplished by microwave irradiation at $750 \mathrm{~W}$ for 15 minutes. After treatment with $10 \%$ normal goat serum for 10 minutes to block nonspecific protein binding, a 1:100 dilution of a mouse monoclonal antibody to p16 (SC1661; Santa Cruz Biochemicals, Santa Cruz, California) was applied for 30 minutes. After reaction with a mouse biotinylated secondary antibody, antigen-antibody reactions were visualized using a streptavidin-horseradish peroxidase conjugate (DAKO LSAB kit; DAKO, Los Angeles, California) with diaminobenzidine as the chromogen. Slides were counterstained with hematoxylin. Normal tissue adjacent to the tumor was used as an internal positive control. Distinct nuclear immunoreactivity was interpreted as the normal immunoreactivity pattern. Tumors lacking nuclear immunoreactivity in all tumor areas were interpreted as negative for p16 immunoreactivity. 


\section{DNA Extraction and MSP}

Tissues were digested in lysis buffer $(10 \mathrm{~mm}$ Tris, $\mathrm{pH}$ 8.5; $10 \mathrm{~mm}$ EDTA; $0.5 \%$ SDS; and100 mM NaCl) with proteinase K $(500 \mu \mathrm{g} / \mathrm{ml}$; Boehringer Mannheim, Mannheim, Germany). Genomic DNA was extracted with phenol-chloroform and precipitated with ethanol. Extracted DNA was modified by sodium bisulfite to determine the methylation status of the $p 16$ gene by MSP as previously described (Herman et al, 1996). PCR was performed at $94^{\circ} \mathrm{C}$ for 5 minutes, followed by 28 cycles at $94^{\circ} \mathrm{C}$ for 1 minute, $65^{\circ} \mathrm{C}$ for 1 minute, and $72^{\circ} \mathrm{C}$ for 1 minute, with a final extension for 10 minutes at $72^{\circ} \mathrm{C}$. The reaction mixture was in a $25 \mu \mathrm{l}$ volume containing $50 \mathrm{ng}$ of modified DNA, $10 \mathrm{pmol}$ of primers, $0.2 \mathrm{~mm}$ dNTP, and 1 unit of Taq polymerase (Takara, Kyoto, Japan) in $1 \times$ PCR buffer (10 mM Tris, $\mathrm{pH}$ 8.3; $50 \mathrm{~mm} \mathrm{KCl}$; and $1.5 \mathrm{~mm} \mathrm{MgCl} \mathrm{M}_{2}$. Sequences of PCR primers were the same as previously described (Herman et al, 1996). The PCR products were analyzed on a $2.5 \%$ agarose gel, stained with ethidium bromide, and visualized by UV illumination. The PCR product was digested with 2 units of ACC II (Takara) for 4 hours, and analyzed on a $2.5 \%$ agarose gel to determine its specificity.

\section{DNA Sequencing}

The PCR products were purified using the JETSORB gel extraction kit (Genomed, Bad Oeynhausen, Germany) and cloned into the pCR2.1-TOPO vector (Invitrogen, Carlsbad, California). Plasmid DNA was extracted from individual clones by alkaline lysis plasmid minipreparation. The inserted PCR fragments of five individual clones obtained from either unmethylated DNA (17U, 23U, and $42 \mathrm{U})$ or methylated DNA (17M, $23 \mathrm{M}$, and $42 \mathrm{M}$ ) were sequenced with both M13 reverse primer and M13 (-20) forward primer using the T7 Sequenase plasmid sequencing kit following the manufacturer's instructions (Amersham Life Science, Buckinghamshire, United Kingdom).

\section{Microsatellite Analysis of $\mathrm{LOH}$}

For the analysis of PCR-based LOH, paired normal DNA and tumor DNA extracted from each sample were analyzed with three microsatellite markers flanking chromosome 9p21: D9S165, D9S171, and D9S1679. PCR was performed in a $25 \mu$ l reaction mixture containing $50 \mathrm{ng}$ of genomic DNA, 10 pmol of primers, $0.2 \mathrm{~mm} \mathrm{dNTP}$, and 1 unit of Taq polymerase (Takara) in 1X PCR buffer (10 mM Tris, pH 8.3; $50 \mathrm{~mm}$ $\mathrm{KCl}$; and $1.5 \mathrm{~mm} \mathrm{MgCl}_{2}$ ). Samples were subjected to $35 \mathrm{PCR}$ cycles with annealing temperatures $\left(50^{\circ} \mathrm{C}\right.$ to $60^{\circ} \mathrm{C}$ ) that varied with the primer. The PCR products $(6 \mu \mathrm{l})$ were mixed with $0.4 \mu \mathrm{l}$ of $1 \mathrm{M}$ methylmercury hydroxide (Johnson Mattey Electronics, Ward Hill, Massachusetts), $2 \mu \mathrm{l}$ of $15 \%$ (weight/volume) Ficoll (MW 400,000) loading buffer containing $0.25 \%$ bromophenol blue and $0.25 \%$ xylene cyanol, and $1.6 \mu \mathrm{l}$ of 1X TBE buffer (90 mM Tris; $92 \mathrm{~mm}$ boric acid; and 2.5 mM EDTA). The resulting PCR products were separated on $6 \%$ denaturing polyacrylamide gels and analyzed at $60 \mathrm{~W}$ for 2 to 3 hours. Silver staining of the gels was performed as previously described (Kang et al, 1999b).

\section{References}

Ahuja N, Mohan AL, Li Q, Stolker JM, Herman JG, Hamilton SR, Baylin SB, and Issa J-P (1997). Association between $\mathrm{CpG}$ island methylation and microsatellite instability in colorectal cancer. Cancer Res 57:3370-3374.

Akama Y, Yashui W, Kuniyasu H, Yokozaki H, Akagi M, Tahara H, Ishikawa T, and Tahara E (1996). Genetic status and expression of the cyclin-dependent kinase inhibitors in human gastric carcinoma cell lines. Jpn J Cancer Res 87: 824-830.

Fleisher AS, Esteller M, Wang S, Tamura G, Suzuki H, Yin J, Zou TT, Abraham JM, Kong D, Smolinski KN, Shi Y-Q, Rhyu M-G, Powell SM, James SP, Wilson KT, Herman JG, and Meltzer SJ (1999). Hypermethylation of the $h M L H 1$ gene promoter in human gastric cancers with microsatellite instability. Cancer Res 59:1090-1095.

Foster SA, Wong DJ, Barrett MT, and Galloway DA (1998). Inactivation of $\mathrm{p} 16$ in human mammary epithelial cells by CpG island methylation. Mol Cell Biol 18:1793-1801.

Gunther TH, Schneuder-Stock R, Pross M, Manger T, Malfertheiner P, Lippert H, and Roessner A (1998). Alterations of the p16/MTS1-tumor suppressor gene in gastric cancer. Pathol Res Pract 194:809-813.

Herman JG, Graff JR, Myohanen S, Nelkin BD, and Baylin SB (1996). Methylation-specific PCR: A novel PCR assay for methylation status of CpG islans. Proc Natl Acad Sci USA 93:9821-9826.

Herman JG, Merio A, Mao L, Lapidus RG, Issa J-P, Davidson NE, Sidransky D, and Baylin SB (1995). Inactivation of the CDKN2/p16/MTS1 gene is frequently associated with aberrant DNA methylation in all common human cancers. Cancer Res 55:4524-4530.

Hsieh C-L (1994). Dependence of transcriptional repression on CpG methylation density. Mol Cell Biol 14:5487-5494.

Hsieh C-J, Klump B, Holzmann K, Borchard F, Gregor M, and Porschen R (1998). Hypermethylation of the p16 ${ }^{\text {INK4a }}$ promoter in colectomy specimens of patients with long-standing and extensive ulcerative colitis. Cancer Res 58:3942-3945.

Igaki $\mathrm{H}$, Sadaki $\mathrm{H}$, Tachimori $\mathrm{Y}$, Kato $\mathrm{H}$, Watanabe $\mathrm{H}$, Kimura T, Harada Y, Sugimura T, and Terada M (1995). Mutation frequency of the $p 16 / C D K N 2$ gene in primary cancers in the upper digestive tract. Cancer Res 55:3421-3423.

Kamb A (1995). Cell-cycle regulators and cancer. Trends Genet 11:136-140.

Kang GH, Shim YH, and Ro JY (1999a). Correlation of methylation of the $h M L H 1$ promoter with lack of expression of hMNL1 in sporadic gastric carcinomas with replication error. Lab Invest 79:903-909.

Kang GH, Yoon GS, Lee HK, Kwon YM, and Ro JY (1999b). Clinicopathologic characteristics of replication error-positive gastric carcinoma. Mod Pathol 12:15-20.

Lee YY, Kang SH, Seo JY, Jung CW, Lee KU, Choe KJ, Kim BK, Kim NK, Koeffler HP, and Bang Y-J (1997). Alterations of p16INK4A and p15INK4B genes in gastric carcinomas. Cancer 80:1889-1896. 
Leung SY, Yuen ST, Chung LP, Chu KM, Chan ASY, and Ho $\mathrm{JCl}$ (1999). $h M L H 1$ promoter methylation and lack of $h M L H 1$ expression in sporadic gastric carcinomas with highfrequency microsatellite instability. Cancer Res 59:159-164.

Liew CT, Li H-M, Lo K-W, Leow CK, Chan JYH, Hin LY, Lau WY, Lai PBS, Lim BK, Huang J, Leung WT, Wu S, and Lee JCK (1999). High frequency of p16INK4A gene alterations in hepatocellular carcinoma. Oncogene 18:789-795.

Liggett WH and Sidransky D (1998). Role of the p16 tumor suppressor gene in cancer. J Clin Oncol 16:1197-1206.

Matsuda $\mathrm{Y}$, Ichida T, Matsuzawa J, Sungimura $\mathrm{K}$, and Asakura H (1999). P16INK4 is inactivated by extensive CpG methylation in human hepatocellular carcinoma. Gastroenterology 116:394-400.

Myohanen SK, Baylin SB, and Herman JG (1998). Hypermethylation can selectively silence individual p16INK4A alleles in neoplasia. Cancer Res 58:591-593.

Schutte M, Hruban RH, Geradts J, Maynard R, Hilgers W, Rabindran SK, Moskaluk CA, Hahn SA, Schwarte-Waldhoff I, Schmiegel W, Baylin SB, Kern SE, and Herman JG (1997). Abrogation of the $\mathrm{Rb} / \mathrm{p} 16$ tumor-suppressive pathway in virtually all pancreatic carcinomas. Cancer Res 57:31263130.

Suzuki H, Itoh F, Toyota M, Kikuchi T, Kakiuchi H, Hinoda Y, and Imai K (1999). Distinct methylation pattern and microsatellite instability in sporadic gastric cancer. Int $\mathrm{J}$ Cancer 83:309-313.
Toyota M, Ahuja N, Ohe-Toyota M, Herman JG, Baylin SB, and Issa J-P (1999a). CpG island methylator phenotype in colorectal cancer. Proc Natl Acad Sci USA 96:8681-8686.

Toyota M, Ahuja N, Suzuki H, Itoh F, Ohe-Toyota M, Imai K, Baylin SB, and Issa J-P (1999b). Aberrant methylation in gastric cancer associated with the $\mathrm{CpG}$ island methylator phenotype. Cancer Res 59:5438-5442.

Vasen HFA, Mecklin J-P, Khan PM, and Lynch HT (1991). The international collaborative group on hereditary non-polyposis colorectal cancer. Dis Colon Rectum 34:424-425.

Wu M-S, Lin Y-W, Sheu J-C, Wang H-P, Wang J-T, Shun C-T, Lee W-J, Wang T-H, and Lin J-T (1996). Intragenic homozygous deletions of MTS1 gene in gastric cancer in Taiwan. Jpn J Cancer Res 87:1052-1055.

Wu M-S, Shun C-T, Sheu J-C, Wang H-P, Wang J-T, Lee W-J, Chen C-J, Wang T-H, and Lin J-T (1998). Overexpression of mutant p53 and c-erbB-2 proteins and mutations of the $p 15$ and $p 16$ genes in human gastric carcinoma: With respect to histological subtypes and stages. J Gastroenterol Hepatol 13:305-310. 